\title{
ENERGY EFFICIENT AND GREEN TECHNOLOGY CONCEPTS
}

\author{
Vinutha Bai $\mathbf{N}^{1}$, DR.R.Ravindra ${ }^{2}$ \\ ${ }^{1}$ Undergraduate student, Civil Department, R.V.College of Engineering, Karnataka, India. \\ ${ }^{2}$ Associate professor, Civil Department, R.V.College of Engineering, Karnataka, India.
}

\begin{abstract}
Green Building encompasses a wide range of design practices, building systems integration, product specification, and construction techniques Green building approach is consistent with the mission of most affordable housing developers, and the most community development corporation mission statements which include language about ensuring that low income people have access to safe, decent and affordable housing

Generally, affordable housing projects utilize readily available, low-to medium-cost materials and systems. Customs products, such as cast-in-place recycled glass terrazzo or elaborate energy system approaches, displacement ventilation, or double-glazed facades, which are found in commercial buildings or custom residential projects, are not usually considered because of detrimental environmental problems. The challenge is to identify opportunities for innovation through the integration of good architectural and mechanical system design with thoughtful and strategic selection of materials, appliances, lighting, and equipment. The paper discusses the various energy efficient and green technology concepts that can be implemented for various structures.
\end{abstract}

Keywords: Green Building, LEED, Resource- Efficient Materials, photo voltaic (PV).

\section{INTRODUCTION}

Green Building, also known as Sustainable Building, is the practice of creating structures and using processes that are environmentally responsible and resource efficient. It encompasses factors such as site selection, design, construction, operation, maintenance, renovation, and deconstruction. Using green building materials and products promotes conservation of dwindling nonrenewable resources internationally. In addition, integrating green building materials into building projects can help reduce the environmental impacts associated with the extraction, transport, processing, fabrication, installation, reuse, recycling, and disposal of these building industry source materials.

The aim of designing a Green Building is to reduce the overall impact of the built environment on human health and the natural environment, shown in Fig-1.

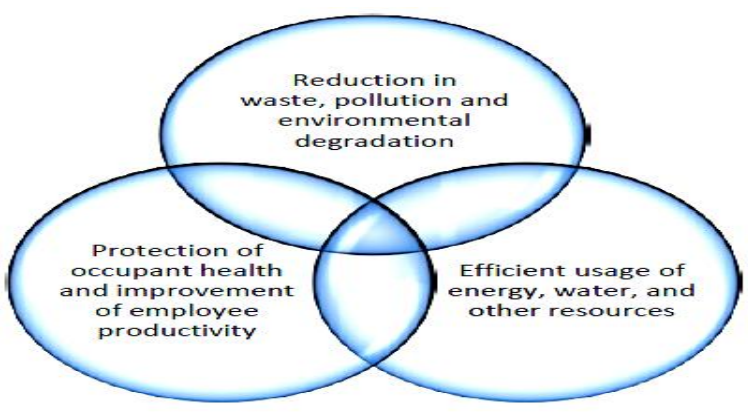

Fig-1: Parameters defining green building concept

\section{LEED-INDIA \& GRIHA}

The Leadership in Energy and Environmental Design (LEED) Green Building Rating System is an India-specific and internationally accepted benchmark for the design, construction and operation of high-performance green buildings. In India, the Indian Green Building Council (IGBC) provides LEED ratings to structures and aims to make the country one of the leaders in green buildings by the year 2015 . The Green Rating for Integrated Habitat Assessment (GRIHA) is the National Rating System of India. It has been conceived by TERI (The Energy and Resources Institute) and developed jointly with the Ministry of New and Renewable Energy, Government of India. It is a design evaluation system for green building and is intended for all kinds of buildings across every climatic zone in India. LEED-INDIA endorses a complete-building approach to sustainability. LEED point distribution is shown in the Fig-2.

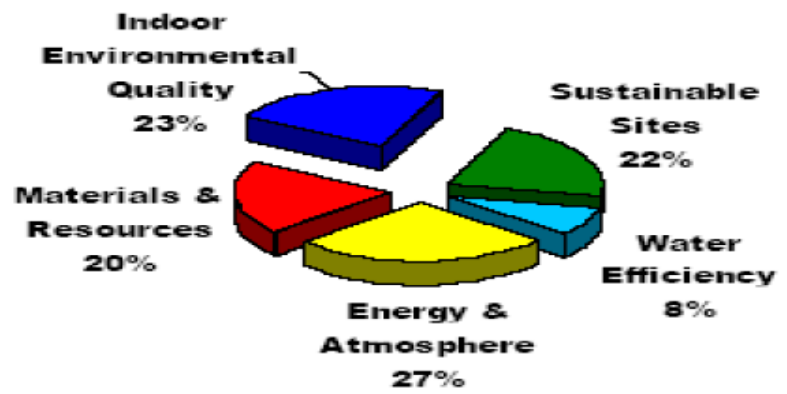

Fig-2: Five LEED Credit Criteria 


\section{PRACTICES IN GREEN \& ENERGY EFFICIENT CONCEPT}

\subsection{Lighting}

It is advisable to maximize the use of available day light and then augment with artificial lighting. While designing the artificial lighting system, the operating expenses over the life of a lighting system can be up to ten times greater than the first cost.

Lighting controls such as photo sensors, occupancy sensors and timers save energy by turning off lights when they are not needed. Timers can be located at a light switch, at a plug, or in a socket and are an inexpensive way to control the amount of time a light stays on, either inside the home or outdoors. By using photo sensors which measures the ambient light level in an area and turn on an electric light, when the level drops below a set minimum. Motion detectors or other occupancy sensors save energy by turning off lights when rooms such as bathrooms or common areas are empty. Dimmers save energy by allowing building occupants to adjust the light outputs to suit their needs. Using LED bulbs instead of other traditional strand lights will reduces energy up to $80 \%$ and has lower maintenance costs [1].

\subsection{Roof Top Gardening}

Insolation by road and building are reduced by roof garden. "If widely adopted, rooftop gardens could reduce the urban heat island, which would decrease smog episodes, problems associated with heat stress and further lower energy consumption. Providing resistance to thermal radiation, rooftop gardens are also beneficial in reducing rain runoff. A roof garden can delay run off; reduce the rate and volume of runoff. Planting roof gardens on tops of building is a great way to make city more efficient. The Fig-3 shows the comparison between reference roof and roof with garden [2]. Roof top garden system consists of various components, to prevent the percolation of water into the roof water proofing membrane has been provided this membrane is incorporated with chemical agents or a physical root barrier, which can be a layer of PVC, polyester or polyethylene has been provided to overcome the root damage to the membrane. Drainage layer has been provided to remove excess water. This can be a layer of gravel, specialized polymer foam panel or a highly porous polymeric mat. To prevent fine particles in the growing medium from clogging the drainage layer a filter layer has been provided and it is of geotextile material. Depending upon the vegetation selected growing medium depth is decided and vegetation is chosen according to their adaptability to local climate conditions. The thermocouple is used to measure the temperature at various spots. Heat flux Transducer helps in generating the flux through which convective, radiative as well as conductive heat can be measured. Moisture sensors measure the water content in soil and RH sensors with respect to air. Through the various data obtained from above instruments the graphs of temperature v/s time has been plotted as shown in the Fig-4

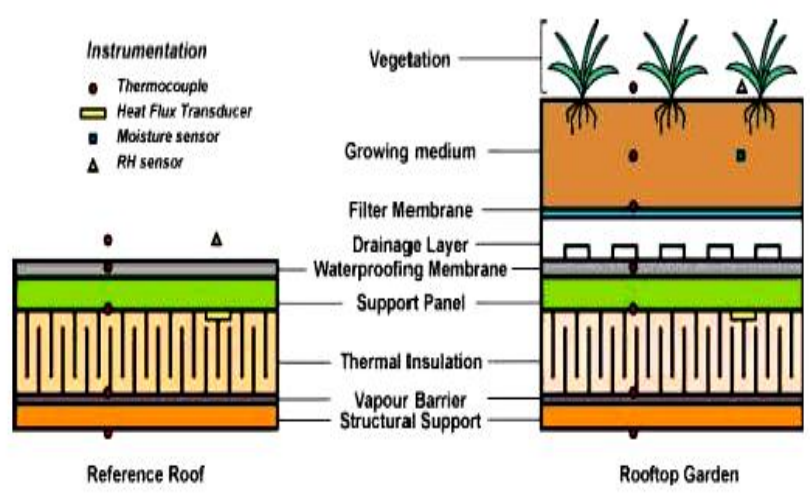

Fig-3: Schematic of components of the roof top garden and reference roof
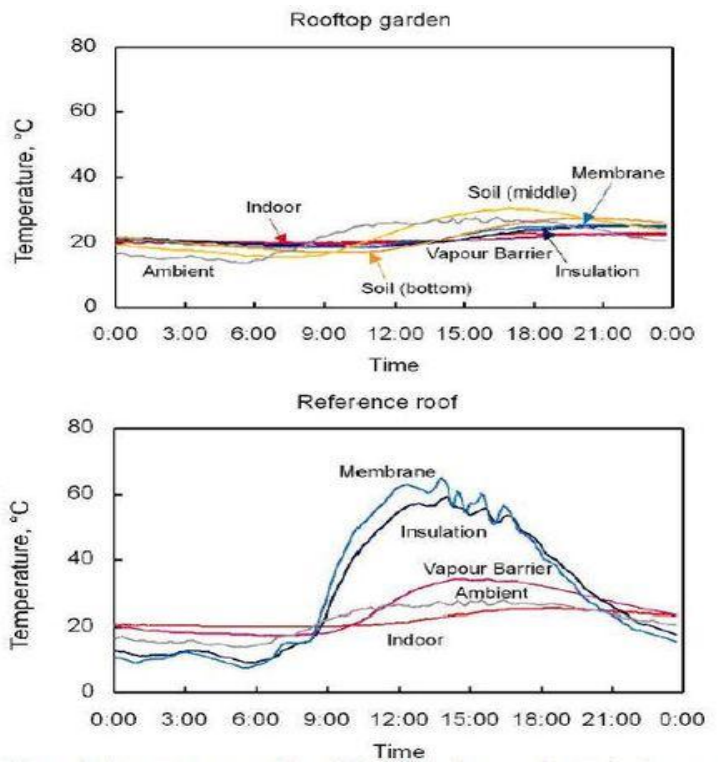

Fig-4: Temperature profile within the rooftop garden and reference roof on a hot sunny, summer day

\section{WATER CONSERVATION}

There are many ways to save water i.e. through conservation, passive rainwater catchment, onsite recycling (i.e., greywater), active rainwater catchment and through ground water recharging techniques. All of these methods actively manage the use of water use. 


\subsection{Recommended Practices for Reducing Water}

\section{Consumption indoors include [1]}

1. Install flow restrictors between the supply line and the kitchen and bathroom faucets to limit water waste.

2. Install shower heads and faucets that use less water than current federal standards.

3. Install high-efficiency toilet (HET) or dual -flush toilets that use less than 1.3 gallons on average per flush, as compare to 1.6 gallons per flush for current models [1].

4. Use locally provided reclaimed water for landscaping. Consider providing separate supply lines to toilets for reclaimed water use in toilet flushing.

\section{SOLAR ENERGY CONCEPTS}

\subsection{Roof Top Solar Photovoltaic System and Solar}

\section{Tracking System:}

One of the best features of rooftop solar PV systems is that they can be permitted and installed faster than other types of renewable power plants. Photovoltaic (PV) or solar cells converts sunlight directly into electricity. They're clean, quiet, and visually unobtrusive. Rooftop PV systems may be installed on top of most large, buildings with large terraces. In a self owned, net metering based rooftop, the electricity generated by the system is first used to service consumer's captive load within the rooftop owner's premises. The solar power generated in excess of the owner's electricity consumption is fed into the grid through a net-meter, which is a bi-directional energy meter. PV installation in home ownership projects are usually $1.5-5 \mathrm{KW}$, which can offset 40 $90 \%$ of electricity use, depending upon the home size and occupant's energy use [1]. Anticipated increase in energy costs can make these systems a cost-effective investment for owners with a ten-year or longer time horizon.

By using the solar tracking system the following advantages can be achieved:

1. Solar tracking systems are used to continually orient photovoltaic panels towards the sun, as a result of which it will increases the effectiveness of panel and generates more power.

2. The space requirement for a solar park can be reduced, even though they maintain the same output.

3. The payback time of the investment is reduced.

\subsection{Solar Water Heater}

Solar water heater economics compare quite favorably with those of electric water heaters. Heating water with the sun also means long-term benefits, such as being cushioned from future fuel shortages and price increases, and environmental benefits. It makes economic sense to think beyond the initial purchase price and consider lifetime energy costs. It found that solar water heaters offer the largest potential savings, with solar water-heater owners saving as much as $50 \%$ to $85 \%$ annually on their utility bills over the cost of electric water heating [3]. Solar water heaters do not pollute. By investing in one, problems related to carbon dioxide, nitrogen oxides, sulfur dioxide, and the other air pollution is avoided and wastes created when the utility generates power or by burning fuel to heat household water. When a solar water heater replaces an electric water heater, the electricity displaced over 20 years represents more than 50 tons of avoided carbon dioxide emissions alone[4]. By this way $\mathrm{Co}_{2}$ responsible for "greenhouse effect." can be avoided.

\section{FUNDAMENTAL PLANNING DECISIONS FOR ENERGY EFFICIENT BUILDING}

\subsection{Site Selection}

Transmission of sunshine through windows (passive solar heating) can reduce heating costs. The selection of a site which is exposed to the low-altitude winter sun can allow for passive solar heating. By selecting a location sheltered from the wind, heat loss from the building can be reduced. Shelter can be provided by nearby trees, adjacent buildings or surrounding hills. If no such shelter exists, it can be provided in time through planting trees or shrubs. In some, mainly rural, locations there may be potential for renewable energy sources other than solar, for example hydropower, wind power, wood, biogas, or heat which can be extracted from the ground or sea. The possibility of obtaining heat from a combined heat and power plant or group heating scheme may also influence the selection of a site.

\subsection{Building Forms and Orientation}

A compact building form of minimum surface-to-volume ratio is best for reducing heat loss. However, a rectangular building with one of the longer facades facing south can allow for increased passive solar heating, day-lighting and natural ventilation. As well as reducing energy costs, sunny southfacing rooms also have high amenity value.

Projections such as bay and dormer windows should be kept to a minimum, since by increasing the surface-to-volume ratio of the building, they will increase heat loss. They also tend to be more difficult to insulate effectively.

Pitched roofs should have one slope oriented south to allow for optimum performance of a roof-mounted or roof-integrated active solar heating system. Even if such a system is not planned during construction, it may be installed at some stage during the life of the building. 


\subsection{Building Fabrics and Insulation}

Insulation should be well distributed around the building shell. It is better to have a good overall level of insulation rather than giving an improper insulation like, a highly insulated floor with no roof insulation.

Attention should be given for the increased heat loss and possible condensation problem caused due to "short circuit" across insulation, which are commonly found at lintels, jambs and sills of doors and windows, and at junctions where floors and ceilings meet external walls.

\subsection{Ventilation}

Adequate ventilation is essential to provide fresh air and to remove moisture, odours and pollutants. However, excessive ventilation during the heating season results in energy wastage and can also cause discomfort due to draughts.

A balanced ventilation system involving fans, ductwork and a heat exchanger can transfer heat from warm stale outgoing air to incoming fresh air (this is called "mechanical ventilation with heat recovery"). Stale air is usually extracted from rooms such as kitchens and bathrooms, and warmed fresh air supplied to living rooms and bedrooms.

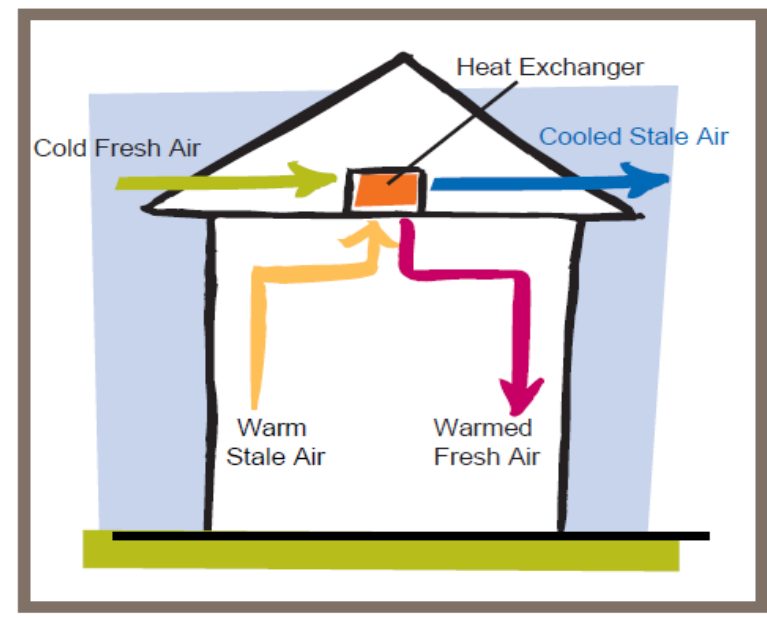

Fig-5: Ventilation [7]

\subsection{Fenestrations and Shadings:}

Fenestrations having $15-20 \%$ of floor area are found adequate for both ventilation and day lighting. Shading devices for windows and walls moderate heat gain into the buildings [5].

\subsection{Finishes}

The external finish of a surface determines the amount of heat absorbed or rejected by it. A smooth and light color surface reflects more light and heat in comparison to a dark color surface. Lighter color surfaces have higher emissivity and should be ideally used for warm climate.

\subsection{Passive Solar Features}

If the house is exposed to the low-altitude winter sun, glazing should be concentrated on the south facade. Window area on the north facade should be minimized to limit heat loss. Windows should have a high resistance to heat loss. 'Low emissivity' double glazing, which has a special coating to reduce heat loss, is required.

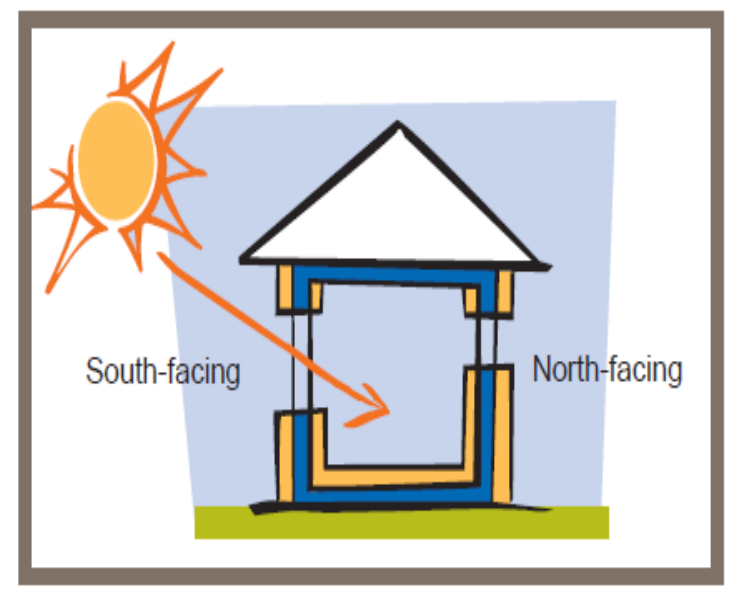

Fig-6: Passive solar features [7]

A well-designed sunspace or conservatory on the south side of a building can reduce the heating needs of a house by acting as a buffer against heat loss and collecting solar energy on fine sunny days. Sunspaces should not be heated, and should be separated from the heated space by walls and / or closable doors / windows. The energy losses from one heated sunspace can negate the savings of ten unheated ones.

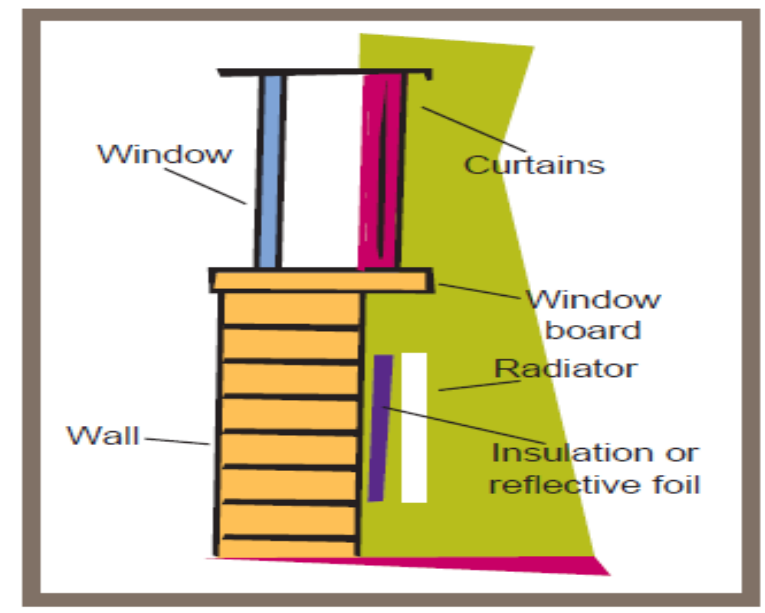

Fig-7: Passive solar feature for window \&wall [7] 


\section{RESOURCE EFFICIENT MATERIALS}

Choice of building materials is important in reducing the energy content of buildings. Strain on conventional energy can be reduced by use of low-energy materials, efficient structural design, and reduction in transportation energy.

\subsection{Stabilized Mud Block (SMB) [6]:}

The stabilized mud block Technology offers a cost-effective, environmentally sound masonry system. This technology is known in India for more than 5 decades. Today, more than 15,000 buildings and houses in about 8 states of India are using the SMB technology for walls. Stabilized earth blocks are manufactured by compacting raw material earth mixed with a stabilized such as cement or lime under a pressure of 20 $-40 \mathrm{~kg} / \mathrm{cm}$. Density and the proportion of cement added are two important criteria, which control the strength and durability of SMB.As the dry density increases from 1.75 $\mathrm{gm} / \mathrm{cc}$ to $1.9 \mathrm{gm} / \mathrm{cc}$ the strength increases from $1 \mathrm{MPa}$ to 2 Mpa.Thus, a $9 \%$ increase in dry density leads to a doubling of the compression strength. As a rule a minimum wet compressive strength of $3.0 \mathrm{MPa}$ is desirable for two storeyed house constructions. A cement percentage of 6 to $7 \%$ and a sand content of $65 \%$ and a clay content of $15 \%$ are usually sufficient to achieve a minimum strength of 3.0 MPa. Using a high percentage of cement, wet compressive strength in a range of 4.0 to $7.0 \mathrm{MPa}$ can be easily achieved. A block with 7.0 $\mathrm{MPa}$ strength can be comfortably recommended for four storeyed load bearing masonry.

Table-1 explains the influence of cement content on compressive strength with soil composition; sand: $65 \%$; silt: $18 \%$; clay: $17 \%$ for the specimen of size $76 \mathrm{~mm} \times 76 \mathrm{mmx} 76 \mathrm{~mm}$.

Table-1: Influence of cement content on compressive strength [6]

\begin{tabular}{|l|l|l|l|l|}
\hline $\begin{array}{l}\text { Cement } \\
\text { content } \\
\text { by } \\
\text { weight, } \%\end{array}$ & $\begin{array}{l}\text { Dry } \\
\text { density } \\
\text { gm/cc }\end{array}$ & \multicolumn{2}{|l|}{ Compression strength,MPa } & $\begin{array}{l}\text { Wet } \\
\text { strength }\end{array}$ \\
\cline { 3 - 5 } & Dry & Wet & $\begin{array}{l}\text { Dry } \\
\text { strength }\end{array}$ \\
\hline 2.5 & 1.87 & 4.54 & 0.77 & 0.17 \\
\hline 5.0 & 1.89 & 9.20 & 2.91 & 0.32 \\
\hline 7.5 & 1.88 & 11.6 & 4.63 & 0.40 \\
\hline 10.0 & 1.91 & 15.0 & 5.82 & 0.39 \\
\hline
\end{tabular}

\section{Advantages:}

- Cost effective, especially when the blocks are produced at the site of use.

- Soil is an easily available resource in rural housing.

- Provides a uniform good strength.

- Provides good thermal comfort.

- Provides aesthetical wall finish, no plaster required.

- Creates additional local employment in block production.

- Can be made with locally available earth which makes it cost effective.

- $\quad$ Thermally comfortable, aesthetically pleasing and one of the most environment friendly alternatives for wall construction.

Recommended practices include the following:

- Use salvaged materials from other buildings, such as the windows, doors, flooring, siding, or large beams.

- Specify landscaping amendments and backfill with recycled contents.

- Use of demolition waste as a reuse or recycle aggregates.

The following Table-2 shows the embodied energy, $\mathrm{CO}_{2}$ emission and density of various building materials.

Table-2: Embodied Energy, $\mathrm{CO}_{2}$ Emission and Density of Various Building Materials.

\begin{tabular}{|l|l|l|l|}
\hline Material & $\begin{array}{l}\text { Energy } \\
\mathrm{MJ} / \mathrm{kg}\end{array}$ & $\begin{array}{l}\text { Carbon } \\
\mathrm{kg} / \mathrm{CO}_{2} / \mathrm{kg}\end{array}$ & $\begin{array}{l}\text { Density } \\
\mathrm{Kg} / \mathrm{m}^{3}\end{array}$ \\
\hline Aggregates & 0.083 & 0.0048 & 2240 \\
\hline $\begin{array}{l}\text { Concrete(1:1.5:3 e.g. insitu } \\
\text { floor slabs, structure) }\end{array}$ & 1.11 & 0.159 & 2400 \\
\hline Bricks(common) & 3 & 0.24 & 1700 \\
\hline $\begin{array}{l}\text { Concrete blocks (Medium } \\
\text { density 10N/mm }{ }^{2} \text { ) }\end{array}$ & 0.67 & 0.073 & 1450 \\
\hline $\begin{array}{l}\text { Steel (general-average } \\
\text { recycled content) }\end{array}$ & 20.10 & 1.37 & 7800 \\
\hline $\begin{array}{l}\text { Steel } \\
\text { recycled content) }\end{array}$ & 21.50 & 1.42 & 7800 \\
\hline $\begin{array}{l}\text { Steel (pipe-average recycled } \\
\text { content) }\end{array}$ & 19.80 & 1.37 & 7800 \\
\hline $\begin{array}{l}\text { Timber (general -excludes } \\
\text { sequestration) }\end{array}$ & 10 & 0.72 & $480-$ \\
\hline $\begin{array}{l}\text { Glass fiber insulation (glass } \\
\text { wool) }\end{array}$ & 28 & 1.35 & 120 \\
\hline Clay tile & 6.5 & 0.45 & 1900 \\
\hline $\begin{array}{l}\text { Aluminium(general } \\
\text { \&incl.33\% recycled) }\end{array}$ & 155 & 8.24 & 2700 \\
\hline Plywood & 15 & 1.07 & $540-$ \\
\hline Glass & 25 & 1.91 & 700 \\
\hline Ceramic tiles & 42 & 2.60 & 8600 \\
\hline Iron (general) & 25.21 & 1.57 & 11340 \\
\hline $\begin{array}{l}\text { Copper (average incl.37\% } \\
\text { recycled) }\end{array}$ & 15 & 2000 \\
\hline Lead (inc.61\% recycled) & 2500 \\
\hline
\end{tabular}




\section{CONCLUSIONS}

The green building concepts helps to maintain the pollution free environment. Green building is a financially, health wise, and most important environmentally responsible idea that more people need to adopt. Many building materials and renewable energy source exists to lessen one's impact upon the environment. Through educating, making environmentally products more readily accessible and reliable, and by providing government incentives it is possible to encourage more people to adopt green building and all of the benefits that come along with it.

\section{REFERENCES}

[1]. Blueprint for Greening Affordable Housing, Edited by walker wells, Island press-2007, chapter $1 \& 3$.

[2]. Construction Technology Update No 65 .Using Garden Roof Systems to Achieve Sustainable Building Envelopes by K.Y. Liu and A. Baskaran, published by institute for research in construction (IRC)-2005.

[3]. Development of Building Regulations and Guidelines to Achieve Energy Efficiency in Bangalore City Published by Tata Energy Research Institute (TERI) chapter9.

[4]. Energy efficiency and renewable energy, DOE/GO10096-050, FS 119, March 1996

[5]. Energy-efficient buildings in India Edited by Mili Majumdar,published by Ministry of Non-conventional Energy Sources and Tata energy research institute(TERI) -2002.

[6]. Alternative building materials and Technologies by K.S.Jagadish,B.V.Venkatarama Reddy,K.S.Nanjunda Rao, New age International publishers ,New Delhi page number2027.

\section{WEB SITES}

[7]. http://www.sei.ie

[8].http://www.teriin.org/events/rooftop-solar-PV-

Exp_mar.pdf

[9].http://www.in.undp.org/content/dam/india/docs/user\%E2\%

80\%99s_handbook_on_solar_water_heaters.pdf

[10].http://nlss.org.in/wp-content/uploads/2012/01/Paper-2-

Jan12.pdf

[11]. www.ecovillage.org.in

[12]. www.mapawatt.com

[13]. http://www.nrel.gov/docs/legosti/fy96/17459.pdf

[14]. http://www.teriin.org/ResUpdate/reep/ch_9.pdf

\section{BIOGRAPHIES}

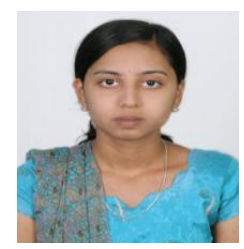

VINUTHA BAI N, B.E Student, Civil Department, R.V.College of Engineering, Bangalore. Field of interest: Structural Engineering \& sustainable technologies.

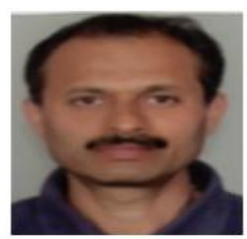

technologies.
DR.R.Ravindra, M.E. (Structures), Ph. D Bangalore University Associate professor, Civil Department, R.V.College of Engineering, Bangalore. Research interest: structural engineering, Alternative Building Materials and sustainable

(1)

